\title{
The Research on Chinese Corruption and the Strategy of Governance
}

\author{
Yongtao $\mathrm{Li}^{1 *}$, Lei Wang² \\ ${ }^{1} \mathrm{Fu}$ Dan Development Institute, Fudan University, Shanghai, China \\ ${ }^{2}$ School of International Trade and Economics, Shandong University of Finance and Economics, Jinan, China \\ Email: *li_yongtao1022@163.com
}

How to cite this paper: Li, Y.T. and Wang, L. (2016) The Research on Chinese Corruption and the Strategy of Governance. Theoretical Economics Letters, 6, 1244-1255. http://dx.doi.org/10.4236/tel.2016.66117

Received: October 28, 2016

Accepted: November 18, 2016

Published: November 21, 2016

Copyright $\odot 2016$ by authors and Scientific Research Publishing Inc. This work is licensed under the Creative Commons Attribution International License (CC BY 4.0).

http://creativecommons.org/licenses/by/4.0/

\begin{abstract}
In recent years, China's economy has gained a great progress, but corruption is still more serious. Firstly, we discuss the strategy of the existing literature combined with the definition of corruption. Secondly, we make the review and analysis of the literature with China's problems. At last, I pay attention to two strategies of the governance of corruption, and I also have the same idea that, to be consistent with that, China should strengthen system construction combining with its own culture tradition on the problem of governance of corruption.
\end{abstract}

\section{Keywords}

Corruption, Governance of Government, Political Economics

\section{(c) (i) Open Access}

\section{Introduction}

In recent years, China's economy has gained a great progress, but corruption is still more serious. From the vertical perspective, the aggregate number of China's Party and Governors who have been reprimanded for the violations of CPC party disciplines was amount to 4.2 million in three decades from 1982 to 2011, of whom 465 served as Governors (Sheng Ji) or Ministers (Bu Ji). In the 11 years between 2003 and 2014, a total of 352 Deputy Departmental Cadres (Fu Ting Ji) or above were punished, of whom departmental level cadres (Ting Ji) accounted for about 60\%, and Provincial and Ministerial level cadres (Sheng/Bu Ji) accounted for about 40\% [1]; since the convening of the 18th National Congress of CPC, 48 Provincial and Ministerial level cadres (Sheng/Bu Ji) had been investigated, among which there were 34 from Local Party and Government Organs, 6 from State Ministries and Commissions, 4 from State-owned companies, 2 from Chinese People's Political Consultative Conference, 1 from Committee of 
Political and Legislative Affairs (Yongkang Zhou), 1 from National People's Congress. Among them, 2 people are above the deputy national level, including Su Rong (Deputy National Level), then the Vice Chairman of CPPCC, Zhou Yong-Kang (National Level), then the member of the Standing Committee of the Political Bureau of the CPC Central Committee and secretary of the Committee of Political and Legislative Affairs. At the same time, the head of Prefecture-level cities under graft investigation has also been increased to 14 people.

From the horizontal perspective, the crime rate of China's ordinary residents is $1 / 400$; the crime rate of state staffs is $1 / 200$; and the crime rate of Judicial staffs is $1.5 / 100$; so the corruption is very serious. Specifically, the scale of corruption is on the rise (the amount of corruption cases in 2000-2009); the median amount of corruption is between $¥ 500,000$ and $¥ 1,300,000$. According to the number of sort, the types of corruption in order to sort are as follows: government procurement, contracting projects, organizational personnel types of corruption, land corruption case (a sharp rise in recent years) [2]. Before 2005, the highest proportion of economic crimes has always been the misappropriation of public funds, but in 2006, bribery cases have become the first, and the degree of enterprise participation has intensified [3].

In sharp contrast, China's fiscal revenue is increasing. According to the public data of People’s Bank of China, in 2012, the balance of China’s treasury deposits reached $¥ 3.23$ trillion, and the balance of "special accounts" at all levels of government reached $¥ 1.42$ trillion, and the total fiscal deposits reached $¥ 465$ million. Meanwhile the revenue of the Chinese government in 2012 reached $¥ 11.72$ trillion; the national public revenue in 2013 reached $¥ 12.91$ trillion. But according to a 2006 report, China’s economic losses caused by corruption in 2003 were as high as $\$ 86$ billion, accounting for $3 \%$ of that year's economic output, posed a "deadly threat" to China's economic development [4]. At the same time, corruption would also bring other negative social impact, such as higher crime rates [5].

Therefore, if the corruption problem still cannot get a better solution, it will bring great challenges to the Chinese government and the ruling ability of the party. In particular, corruption may harm them in the following ways. First, corrupt officials will reduce the effectiveness of government policies, and lose public trust; and second, corruption will weaken the ruling ability of the Communist Party; once again, corrupt officials will seriously distort the allocation of government resources, and will further distort the market by intervening in the market resource allocation; and finally, corrupt officials will distort the selection criteria of government talent, and impact on the legitimacy of the ruling party.

\section{The Definition of Corruption and Research Strategies}

Corruption is often considered as a private abuse of public authority (from Transparency International) ${ }^{1}$, or a misuse of public assets for private gain(World Bank, 1997). The economists' research on corruption mainly focuses on two aspects: the causes of

\footnotetext{
${ }^{1}$ See the definition of corruption from Transparency International.
} 
corruption and the consequences of corruption [6]. At the same time, well-known scholar Chalmers Johnson believes that corruption is a mechanism for the delivery of benefits. Through this mechanism, enterprises contribute part of the profits to the relevant politicians, and then establish a "stable political interest alliance", the final two sides have access to additional higher revenue, and distort the allocation of resources.

Since corruption is difficult to measure and has privacy, there are some difficulties in this research, at this stage there are several following research methods: 1) Investigation Perception: this approach mainly uses the questionnaire to study corruption, such as analysis with the Corruption Perception Index of Transparency International Index, the World Governance Index of World Bank and other indicators as alternative variable for corruption [7] [8] . 2) On-site Audit: Researchers use technologists to re-evaluate government-sponsored projects and compare the differences between actual project costs (Assess Costs) and government published costs [9]. 3) Exogenous Shock: mainly based on (quasi)natural experiments to study the changes in corruption under the exogenous shock, such as the impact of environmental(legal and policy) change on official corruption [10], or the impact of changes in leaders' physical health on political affiliation [11] [12]. 4) The use of experimental economics to study the factors that affect corruption and governance measures [13] [14] [15] [16].

As far as the research method is concerned, the above methods have advantages and disadvantages. In the absence of sufficiently detailed data, the first approach may be a better choice, but it may be difficult to know exactly how the internal mechanisms of corruption operate; The second method, although it can accurately understand the corruption and its inherent costs, but will bring a greater financial burden to the research; The third method requires investigators to check strictly whether the shock is exogenous. The last method provides a new perspective for the understanding of corruption, but it poses a serious challenge to the extensions of experimental design and results.

\section{The Strategy of Corruption Governance in China and Comment}

Communique of the Fourth Plenary Session of the 18th Central Committee of the Communist Party of China stressed "remained committed to fighting corruption". The China's central government has taken various measures to tackle the problem of corruption, but in general, it can be divided into two types: Blocking and Dredging. Blocking aspects, mainly refers to the strengthening of legal punishment, such as increasing the number and breadth of central inspections (in 2013, the central government sent two rounds of Central Leading Groups for Inspection Work to carry out a

${ }^{2}$ October 23 (Reuters)-Communiqué of the Fourth Plenary Session of the 18th Central Committee of the Communist Party of China: "To adjust to the new normal in China's economic development, the Political Bureau has created new ways of thinking and methods for regulating at the macro level, worked to solve problems hindering economic and social development, and strived to provide safeguards for and improve the people's standard of living. It has also basically completed the campaign to heighten awareness of and implement the Party's mass line, remained committed to fighting corruption, and responded effectively to all kinds of risks and challenges. It has thus made fresh progress in all its work and ushered in a new stage of development for the cause of the Party and country". 
nationwide review); dredging aspects, mainly by improving the specific socio-economic environment in which crime is perpetrated, such as strengthening personnel construction, the optimized leadership election and improve the corresponding government system, emphasizing the party and government to "put power into the sys$t^{3}{ }^{3 \prime}$. So for the current stage of corruption in China, governance should be most still mainly to blocking, or to dredging? On the one hand, from an economic point of view, corruption can be considered as the optimal behavior choice of the rationality agents (officer) under a series of constraints [17] [18] [19]. The rational person's choice of whether or not to commit a crime depends on the probability of exposure to corruption (the probability of being caught afterwards) and the intensity of punishment. So the government can increase the intensity of judicial expenditure or punishment and thus improve the effectiveness of the potential deterrent to corruption and eventually reduce the corruption of officials. On the other hand, in a rapidly transitional and developing country like China, the social and economic factors that lead to corruption have their own era characteristics and their own institutional characteristics, which need to be given guidance and perfection. For example, the inequality of government's attitude to business is caused by the inequality of domestic property rights, and corporate bribery is just a means to protect their property rights [20] [21]. At the same time, some studies have found that corruption has two meanings in China: in terms of promoting economic growth, relevant research suggests that corruption acts as an "economic lubricant", helping businesses or individuals to bypass inefficient government work, and bribery may also help government employees to improve working efficiency [22] [23]; in terms of hindering economic growth, relevant research has focused mainly on the fact that corruption distorts resource allocation as a "grabbing hand", thereby hampering economic growth [24] [25] [26]. In addition, some related studies that there are inverse $\mathrm{U}$ relations between corruption and economic growth [27].

Specifically, what effect should these two kinds of anti-corruption type achieve? Blocking aspects, although the increase in the amount of judicial punishment can increase the probability of officials being caught afterwards, thereby reducing the corruption incentives of officials, but when officials start collusion, such as corporate corruption (this is very common in corruption) $)^{4}$, which often makes the effectiveness of judicial investment reduced, and because government projects often have a variety of forms, which led to the monitoring effect is often not the same [9]. Although the government in the short term to increase judicial investment, such as the national inspection can bring some deterrent effect, however, in view of the hidden nature of corruption, when it was discovered to expose, corruption has caused a greater harm and resource allocation distortion to the relevant people. Based on the analysis of 72 provincial and ministerial corrupt officials from 2003 to 2011, it can be found that the average time span for corruption and arrest is 8.5 years, which in fact has brought a great waste

\footnotetext{
${ }^{3}$ See the speech made by general secretary Xi Jinping at the Second Plenary Session of the Central Commission for Discipline Inspection.

${ }^{4}$ For example, Professor Xu Yan, Dean of the School of Psychology of Beijing Normal University, emphasized that some officials were pulled into corrupt groups because of "psychological bundling".
} 
of resources to the society ${ }^{5}$. Dredging aspects are mainly emphasizing the construction of incentive mechanism, institutional and organizational environment. In the aspect of incentive mechanism, the goal of the government is multiplicity, and the task of the government is difficult to measure. Therefore, when the incentive mechanism is designed (the mode of wage setting), the government cannot adopt the highly incentive and only adopt the lowly incentive method $[28]^{6}$. In the institutional environment, the promotion mechanism, reputation mechanism and the term of office will affect the behavior of officials [21] [29] $]^{7}$, so it is necessary to rationally construct the corresponding institutional environment. In the organizational environment, structural differences within the organization will also affect the efficiency of people to complete the task [30] [31] [32] [33], so it is also necessary to consider the organizational model within the government.

To sum up, taking into account the seriousness and urgency of the current corruption, in the short term, the government should strengthen the judicial punishment; and in the long run, the government should improve its own organizational building and strengthen the supervision of society and the party.

\section{The Suggestions of Corruption Governance in China}

The "Decision" of the Third Plenary Session of the 18th Central Committee of the Communist Party of China stressed "get rid of defects in various systems and mechanisms, and strive to open up broader prospects for socialism with Chinese characteristics". But also stressed that "the overall goal of deepening the reform comprehensively is to improve and develop socialism with Chinese characteristics, and to promote the modernization of the national governance system and capacity"; and the implementation of political reform requires us to examine the external rules and institutional environment of strategic interaction with political players [34], as well as the corruption governance.

\footnotetext{
${ }^{5}$ That is, corruption officials have been punished for almost nine years after corrupt practices, such as corruption or bribery for the first time, see Research Report on the Politics of Contemporary China.

${ }^{6}$ In fact, a lot of problems were caused by the strong motivation of the government to implement a single goal. The central government has clearly recognized this point and wrote it in the Decision of the Centra Committee of the Communist Party of China on Some Major Issues Concerning Comprehensively Deepening the Reform: We will improve the development progress evaluation system, correct the bias of evaluating political achievements merely by the economic growth rate. We will increase the weight of other evaluation indicators such as resources consumption, environmental damage, ecological benefits, excess production capacity, sci-tech innovation, production safety and new debts, while more emphasis will be put on employment, residents' income, social security and public health.

${ }^{7} \mathrm{Ni}$ Xing, Executive Director of Center for Anti-Corruption Studies of Sun Yat-sen University, studied sub-provincial city data from 2000 to 2010 , found that the longer the term of secretary of the municipal party committee, the higher the level of regional corruption. See http://www.infzm.com/content/96826. And when officials are nearing the date of promotion (within a year), companies will use political connections to accelerate the IPO, see Joseph D. Piotroski, Tianyu Zhang. Politicians and the IPO decision: The impact of impending political promotions on IPO activity in China, Journal of Financial Economics, 2014.01; 111(1): 111136. At the same time, the study found that: the provinces with large anti-corruption efforts, usually with the central "airborne" leaders, the public more trust in their legal system, see Zhu, B., 2014, MNCs, Rents and Corruption: Evidence from China. Princeton IR Faculty Colloquium.
} 
From the experience of various countries, although there is no strict specific answer to anti-corruption, the institutional arrangement of anti-corruption must be combined with the country's own cultural traditions and social systems in order to produce more effective results [35] [36], and cannot ignore the role of traditional cultural and customs [37], therefore, the problem of corruption governance in China needs to find the corresponding solution from China itself. The study found that the incidence of corruption in China is highly correlated with the government's own institutional arrangements and social institutional arrangements $[38]^{8}$. In the short run, the government can increase the anti-corruption investigation and the corresponding patrol system to reduce corruption. But in the long run, the government must complete its own corresponding institutional construction and corresponding social institutional construction. Only in this way can the corruption be reduced from the root. In fact, the Communiqué of the Fourth Plenary Session of the 18th Central Committee also highlighted this point, namely, comprehensively advancing the law-based governance of the country: "Under the CPC's leadership, we need to uphold socialism with Chinese characteristics; put into practice the theory of socialist rule of law with Chinese characteristics; form a complete system of laws and regulations, a highly effective system to ensure the rule of law is put into effect, a stringent system to oversee the implementation of the rule of law, and a robust system to guarantee the rule of law; put in place a well-defined system of Party rules and regulations; make coordinated efforts to promote law-based governance, law-based exercise of state power, and law-based administration of government; adopt a holistic approach to the development of a rule of law country, government, and society; ensure that a scientific approach is taken to legislation, that law is enforced strictly, that justice is administered impartially, and that the law is observed by everyone; and modernize our country's governance system and capacity for governance". And stressed that "to improve the socialist system of laws with Chinese characteristics, at the heart of which is the Constitution, and strengthen the implementation of the Constitution; to thoroughly advance the administration of government on the basis of the law and accelerate our efforts to build a rule of law government; to ensure judicial impartiality and improve judicial credibility; to strengthen the notion of the rule of law among all Chinese people and drive forward the development of a rule of law society; to raise the level of competence of rule of law professionals; and to strengthen and improve the Party's leadership over efforts to comprehensively advance the law-based governance of the country".

Corruption is the use of public power in the hands of government officials to seek private interests, and then in the context of rule by law, based on the environment, subject and object of corruption, this article briefly proposes the corresponding suggestions or measures, specifically including the following aspects.

1) Social Environment: this refers to the establishment of fair and equitable legal en-

${ }^{8}$ Birney stressed that China's own administrative system increased the concealment of corruption, that is, the "administrative order" -led regulatory structures increased the difficulty of "discovery and identification" of corruption. 
vironment ${ }^{9}$, the implementation of a broader reporting system with accountability, and a wider and more liberal media communication system (in particular, the disclosure mechanism of corruption).These measures will, to a certain extent, increase the deterrence of corruption, and the study found that with the increase in the number of graduates of higher education (education), people will increase the demand for speech, and government regulation will only deepen people's mistrust for government, resulting in negative effects [39]. Finally, a leniency mechanism can be established for whistleblowers, since such measures can reduce the commitment of "conspiracy to corrupt" [40].

2) Market Environment: this refers to the establishment of an equal enterprise market environment, the free exit mechanism for enterprises [41], while adjusting the relationship between government officials and state-owned enterprises [42].

3) Government: the government should reasonably control the size [43] and decentralization [44], improve the internal consultation system [45], at the same time, strengthen the system of power balance, establish the accountability system, transparentize government administrative system [46] and reduce opportunities of intervention in the markets by the government (such as various approval), thereby reducing the chance of government corruption at the source.

4) Officials: this refers to the reasonable selection of suitable personnel $[47]^{10}$, the establishment of effective promotion mechanism [48] [49], reputation mechanism, rotation system [50], cadres exchange in a new spot [51], term of office [52]; Finally, the government can refer to the national wage level, to consider raising official wages, which will increase the corruption costs of officials, but the program is implemented on the premise that the efficiency of the government office to improve and scale down.

5) Public Projects Decision-Making: the government can take collective decision-making, thereby increasing the cost of corruption coordination and reduce the probability of corruption [53] [54] [55] [56 $]^{11}$; at the same time in the implementation of government projects, which can implement the "four-eyes principle"12, and conduct targeted supervision of public affairs ${ }^{13}$.

\section{Summary and Conclusion}

Hu Jintao in the report of 18th National Congress said: "If the corruption problem ${ }^{9} \mathrm{With}$ regard to the establishment of an equitable legal environment, the Communiqué of the Fourth Plenary Session of the 18th Central Committee has emphasized that: "Justice is the lifeblood of the rule of law. Judicial justice greatly encourages social justice, while judicial injustice cripples it. We must improve the system for managing the judiciary and the mechanisms for the exercise of judicial powers, standardize judicial behavior, tighten oversight of judicial activities, and make every effort to ensure that the people feel justice is served in every case that comes before the court".

${ }^{10}$ The great charm of power is that it can bring benefits, but behavioral economics study found that when the power does not bring income, people still have a strong will to grasp the power, mainly because the lack of power and regret will exacerbate people's struggle for power, so the need for institutional environment and the durability of the appropriate public servants.

${ }^{11}$ Some experimental economics studies have found that decision making is more rational than individual decision making.

${ }^{12}$ For major projects bidding, financial-related expenditures and police law enforcement, these matters must adhere to two or more checks, in order to prevent black-box operation, don't allow individuals to act alone.

${ }^{13}$ Because of the difference in project and supervision (project participants and top-down officials), the effect will be different. 
cannot be solved well, it will cause fatal injuries to the party, and even the death of the party and the nation". In the first collective learning conference of the Eighth Politburo of the CPC Central Committee, Xi Jinping talked about the status of the current stage and has repeatedly stressed: "Things Must Corrupted before Got Grubby". At this stage, China is facing a relatively severe corruption situation, which will have a greater negative impact on national economic and social development [5] [10] [57] [58] [59] ${ }^{14}$. Therefore, if we cannot deal with this problem well, it will bring long-term harm to the country and society: for example, serious corruption will reduce people's trust in the government, and trust is an important indicator of social capital, and once social capital is reduced, social corruption will exacerbate and then form a feedback mechanism and worsen economic development. As a result, the implementation of any policy in the future will be less effective.

Considering the importance of corruption, this article first outlines the current corruption and anti-corruption situation based on official statistics. Then, with the definition of corruption, the author introduces the main research methods. At the same time, based on the review of the above literature, this article emphasizes the connotation, advantages, disadvantages and the concrete practice suggestions of the two kinds of anticorruption strategies. For the current anti-corruption, the social environment, market environment, government and the ruling party need reasonable disposal from short and long term, and strengthen supervision.

Although how to solve the problem of corruption is very important, "what kind of governance system a country chooses is determined by its historical heritage, cultural tradition and the level of social economic development, and by the people of this country. China's national governance system today is the result of long-term development, gradual improvement and endogenous evolution on the basis of China's historical heritage, cultural tradition and the level of social economic development" ${ }^{\prime 5}$. Corruption governance is also true, which needs based on China's actual conditions and historical conditions, to find a more suitable governance pattern for China.

Finally, although this paper analyzes the corruption, the current situation of China's corruption and the countermeasures in detail from the point of view of literature, it does not propose a relatively strict theoretical framework. Therefore, this paper hopes that the future research can further expand in this area and deepen the understanding of corruption and China's economic and political development.

\section{References}

[1] Nie, H.H. and Wang, M.Q. (2014) The Impact of Political Cycles on Combating Corruption: Evidence from Chinese Bureau-level Corruption Cases during 2003-2013. Comparative Economics \& Social Systems, 127-140.

[2] Gong, T. and Wu, M.L. (2012) A Research Report on China's Corruption Cases during

${ }^{14}$ There is much to say in this regard, since corruption can lead to distortions in resource allocation and other related phenomena, such as in countries with high levels of corruption, where crime rates are often high.

${ }^{15}$ See Xi Jinping February 17, 2014 speech at the opening ceremony of the seminar of provincial and ministerial level leading cadres of studying and implementing the Third Plenary Session of the 18th Central Committee of the CPC spirit and the continuous deepening reform. 
2000-2009: Empirical Analysis of Some 2800 Corruption Cases. Sociological Study, 204-220.

[3] Ko, K. and Weng, C.F. (2012) Structural Changes in Chinese Corruption. The China Quarterly, 211, 1-23.

[4] Pei, M.X. (2006) China's Trapped Transition: The Limits of Developmental Autocracy. Harvard University Press, Cambridge. https:/doi.org/10.4159/9780674041981

[5] Bó, P.D. and Tella, R.D. (2002) "Plata o Plomo?”: Bribe and Punishment in a Theory of Political Influence. American Political Science Review, 100, 41-53.

[6] Nie, H.H. (2014) The Impact of Corruption on Economic Efficiency: A Survey. Chinese Review of Financial Studies, 1-13.

[7] Li, H. (2013) Secularism and Corruption: A Quantitative Analysis Based on Cross-Country Dataset. Comparative Economics \& Social Systems, 183-198.

[8] Okadaa, K. and Samrethb, S. (2012) The Effect of Foreign Aid on Corruption: A Quantile Regression Approach. Economics Letters, 115, 240-243.

https:/doi.org/10.1016/j.econlet.2011.12.051

[9] Olken, B. (2010) Monitoring Corruption: Evidence from a Field Experiment in Indonesia, Journal of Political Economy, 115, 200-249. https:/doi.org/10.1086/517935

[10] Fisman, R. and Svensso, J. (2007) Are Corruption and Taxation Really Harmful to Growth? Firm Level Evidence. Journal of Development Economics, 83, 63-75. https:/doi.org/10.1016/j.jdeveco.2005.09.009

[11] Fisman, R., Fisman, J., Galef, J., Khurana, R. and Wang, Y. (2012) Estimating the Value of Connections to Vice-President Cheney. The Journal of Economic Analysis \& Policy, 12, 120. https:/doi.org/10.1515/1935-1682.3272

[12] Della Vigna, S., Durante, R., Knight, B. and La Ferrara, E. (2014) Market-Based Lobbying: Evidence from Advertising Spending in Italy. CEPR Discussion Paper 9813/NBER Working Paper No. 19766.

[13] Barr, A. and Serra, D. (2010) Corruption and Culture: An Experimental Analysis. Journal of Public Economics, 94, 862-869. https:/doi.org/10.1016/j.jpubeco.2010.07.006

[14] Armantier, O. and Boly, A. (2011) Can Corruption be Studied in the Lab? Working Paper, University of Montreal, Montreal.

[15] Armantier, O. and Boly, A. (2012) On the External Validity of Corruption Experiments. In: Serraand, D. and Wantchekon, L., Eds., New Advances in Experimental Research on Corruption, Research in Experimental Economics Vol. 15, Emerald Group Publishing, Bingley, 117-144. https:/doi.org/10.1108/S0193-2306(2012)0000015007

[16] Mansour, S., Sadiraj, V. and Wallace, S. (2014) Political Institutions and Corruption: An Experimental Examination of the "Right to Recall". CIE Working Paper Series No. 2014-06.

[17] Becker, G.S. (1968) Crime and Punishment: An Economic Approach. Journal of Political Economy, 76, 169-217. https:/doi.org/10.1086/259394

[18] Becker, G.S. (1974) Essays in the Economics of Crime and Punishment. Landes, W.M., Ed., Columbia University Press for the National Bureau of Economic Research, Columbia.

[19] Olken, B. and Pande, R. (2014) Corruption in Developing Countries. Annual Review of Economics, 4, 479-505. https:/doi.org/10.1146/annurev-economics-080511-110917

[20] Cai, H., Fang, H. and Xu, L. (2011) Eat, Drink, Firms and Government: An Investigation of Corruption from Entertainment and Travel Costs of Chinese Firms. Journal of Law and Economics, 54, 55-78. https:/doi.org/10.1086/651201

[21] Piotroski, J.D. and Zhang, T. (2014) Politicians and the IPO Decision: The Impact of Impending Political Promotions on IPO Activity in China. Journal of Financial Economics, 
111, 111-136. https:/doi.org/10.1016/j.jfineco.2013.10.012

[22] Sun, G., Lu, M. and Zhang, J. (2005) Anticorruption, Market Construction and Economic Growth. China Economic Quarterly, 1-22.

[23] Wedeman, A. (2014) Double Paradox: Rapid Growth and Rising Corruption in China. China Citic Press, Beijing.

[24] Liu, Y. and Feng, H. (2011) Corruption, Public Expenditure Efficiency and Economic Growth. Economic Research Journal, 46, 17-28. https:/doi.org/10.1016/j.chieco.2004.06.009

[25] Shleifer, A. and Vishny, R. (1993) Corruption. Quarterly Journal of Economics, 108, 599617. https:/doi.org/10.2307/2118402

[26] Paolo, M. (1995) Corruption and Growth. Quarterly Journal of Economics, 110, 681-712. https:/doi.org/10.2307/2946696

[27] Méon, P.-G. and Weill, L. (2010) Is Corruption an Efficient Grease? World Development, 38, 244-259. https:/doi.org/10.1016/j.worlddev.2009.06.004

[28] Aghion, P. and Tirole, J. (1997) Formal and Real Authority in Organizations. Journal of Political Economy, 105, 1-29. https:/doi.org/10.1086/262063

[29] Zhu, B. (2014) Rents and Corruption: Evidence from China. Princeton IR Faculty Colloquium, Princeton University, Princeton.

[30] Paul, M. and Roberts, J. (1992) Economics, Organization, and Management. Prentice Hall, Upper Saddle River.

[31] Qian, Y. and Xu, C. (1993) Why China's Economic Reform Differ: The M-Form Hierarchy and Entry/Expansion of the Non-State Sector. Economics of Transition, 1, 135-170. https:/doi.org/10.1111/j.1468-0351.1993.tb00077.x

[32] Maskin, E., Qian, Y. and Xu, C. (2000) Incentives, Information, and Organizational Form. Review of Economic Studies, 67, 359-378. https:/doi.org/10.1111/1467-937X.00135

[33] Qian, Y., Roland, G. and Xu, C. (2006) Coordination and Experimentation in M-Form and U-Form Organizations. Journal of Political Economy, 114, 366-402. https:/doi.org/10.1086/501170

[34] Dixit, A. (2003) On Modes of Economic Governance. Econometrica, 71, 449-481. https:/doi.org/10.1111/1468-0262.00415

[35] Yang, K. (2009) Institutional Congruence, Ideas, and Anticorruption Policy: The Case of China and the United States. Public Administration Review, 69, 142-150. https:/doi.org/10.1111/j.1540-6210.2009.02102.x

[36] Paolo, M. (2004) The Persistence of Corruption and Slow Economic Growth. IMF Staff Papers 51, 1-18.

[37] Raymond, F. and Miguel, E. (2007) Corruption, Norms and Legal Enforcement: Evidence from Diplomatic Parking Tickets. Journal of Political Economy, 115, 1020-1048. https:/doi.org/10.1086/527495

[38] Mayling, B. (2014) Decentralization and Veiled Corruption under China's "Rule of Mandates". World Development, 53, 55-67. https:/doi.org/10.1016/j.worlddev.2013.01.006

[39] Zhu, J., Lu, J. and Shi, T. (2013) When Grapevine News Meets Mass Media: Different Information Sources and Popular Perceptions of Government Corruption in Mainland China. Comparative Political Studies, 46, 920-946. https:/doi.org/10.1177/0010414012463886

[40] Serra, D. (2012) Combining Top-Down and Bottom-Up Accountability: Evidence from a Bribery Game. Journal of Law, Economics and Organization, 28, 569-587.

https:/doi.org/10.1093/jleo/ewr010 
[41] Niehaus, P. and Sukhtankar, S. (2013) The Marginal Rate of Corruption in Public Programs: Evidence from India. Journal of Public Economics, 104, 52-64. https:/doi.org/10.1016/j.jpubeco.2013.05.001

[42] Aharony, J., Jevons Lee, C. and Wong, T.J. (2000) Financial Packaging of IPO Firms in China. Journal of Accounting Research, 38, 103-126. https:/doi.org/10.2307/2672924

[43] Zhou, L. and Tao, J. (2009) Government Size, Market Development and Corruption. Economic Research Journal, 1, 57-69.

[44] Albornoz, F. and Cabrales, A. (2013) Decentralization, Political Competition and Corruption. Journal of Development Economics, 105, 103-111. https:/doi.org/10.1016/j.jdeveco.2013.07.007

[45] Lin, S. (2003) Political Consultation: A Reflection on the Development of Chinese Democratic Politics. Academic Monthly, 755-766.

[46] Peisakhin, L. and Pinto, P. (2010) Is Transparency an Effective Anti-Corruption Strategy? Evidence from a Field Experiment in India. Regulation and Governance, 4, 261-280. https:/doi.org/10.1111/j.1748-5991.2010.01081.x

[47] Fehr, E. (2013) The Lure of Authority: Motivation and Incentive Effects of Power. American Economic Review, 103, 1325-1359. https:/doi.org/10.1257/aer.103.4.1325

[48] Zhou, L. (2007) Governing China's Local Officials: An Analysis of Promotion Tournament Model. Economic Research Journal, 36-50.

[49] Yang, Q. and Zheng, N. (2013) The Promotion Competition of Local Leadership Is the Yardstick Competition, Tournament or Qualification. The Journal of World Economy, 130156.

[50] Abbink, K. (2004) Staff Rotation as an Anti-Corruption Policy: An Experimental Study. European Journal of Political Economy, 20, 887-906. https:/doi.org/10.1016/j.ejpoleco.2003.10.008

[51] Fan, Z. (2014) Government-Enterprise Collusion and Enterprise Tax Evasion: Evidence from Cadres Exchange of State Tax Bureau Chief. Working Paper.

[52] Ni, X. and Chen, S. (2013) Economic Structure, Institutional Arrangement and Regional Corruption: An Analysis Based on Sub-Provincial Cities from 2000 to 2010. Journal of Sun Yat-sen University, 138-150.

[53] Cooper, D.J. and Kagel, J.H. (2005) Are Two Heads Better than One? Team versus Individual Play in Signaling Games. American Economic Review, 95, 477-509. https:/doi.org/10.1257/0002828054201431

[54] Cox, J.C. and Hayne, S.C. (2006) Barking up the Right Tree: Are Small Groups Rational Agents? Experimental Economics, 9, 209-222. https:/doi.org/10.1007/s10683-006-9123-3

[55] Kocher, M.G. and Matthias, S. (2015) The Decision Maker Matters: Individual versus Group Behaviour in Experimental Beauty-Contest Games. The Economic Journal, 115, 200-223. https:/doi.org/10.1111/j.1468-0297.2004.00966.x

[56] Kugler, T., Bornstein, G., Kocher, M.G. and Sutter, M. (2007) Trust between Individuals and Groups: Groups Are less Trusting than Individuals but just as Trustworthy. Journal of Economic Psychology, 28, 646-657. https:/doi.org/10.1016/j.joep.2006.12.003

[57] Mauro, P. (1995) Corruption and Growth. Quarterly Journal of Economics, 110, 681-712. https:/doi.org/10.2307/2946696

[58] Knack, S. and Keefer, P. (1995) Institutions and Economics Performance: Cross Country Tests Using Alternative Institutional Measures. Economics and Politics, 7, 207-227. https:/doi.org/10.1111/j.1468-0343.1995.tb00111.x 
[59] Méon, P.-G. and Sekkat, K. (2005) Does Corruption Grease or Sand the Wheels of Growth? Public Choice, 122, 69-97. https:/doi.org/10.1007/s11127-005-3988-0

Submit or recommend next manuscript to SCIRP and we will provide best service for you:

Accepting pre-submission inquiries through Email, Facebook, LinkedIn, Twitter, etc. A wide selection of journals (inclusive of 9 subjects, more than 200 journals)

Providing 24-hour high-quality service

User-friendly online submission system

Fair and swift peer-review system

Efficient typesetting and proofreading procedure

Display of the result of downloads and visits, as well as the number of cited articles

Maximum dissemination of your research work

Submit your manuscript at: http://papersubmission.scirp.org/

Or contact tel@scirp.org 